\title{
ATOS DE FALA E A LEI
}

\author{
Speech acts and the law
}

\author{
Jacob L. Mey ${ }^{1}$ \\ (University of Southern Denmark - UD)
}

\begin{abstract}
The present article endeavors to put the old question of the 'force of words' into a pragmatic perspective, especially insofar as the law and legal texts are concerned. Questioning the wisdom of the old adage "Saying it don't make it so", I show that words do have an effect (which philosophers and linguists have tried to capture, using the concepts of 'speech act' or 'pragmatic act'), and that the legal constituents of this 'force' are precisely what makes contractual acts valid. Here, too, words sometimes may be omitted, or substituted by actions, provided the context allows for it. Based on a few historical and contemporary cases, the article demonstrates furthermore how words indeed make a difference in a variety of legal and other societal contexts. The pragmatic (that is, user-oriented) angle is always paramount, and our words should obey the pragmatic conditions, often called 'affordances', of the situation in which they are being uttered.
\end{abstract} Keywords: speech (pragmatic) acts, legal norms, contracts, sequentiality

\section{RESUMO}

O presente artigo busca colocar a velha questão da 'força das palavras' em uma perspectiva pragmática, especialmente na medida em que a lei e os textos legais são colocados em questão. Ao se questionar a sabedoria

1. Professor Emeritus of Linguistics at the University of Southern Denmark. Jacob Mey holds honorary Dr. Phil. degrees from the Universities of Zaragoza, Spain (1993) and Bucharest, Romania (2006). In 2008, he was presented with a Life Time Award from the University of Southern Denmark for his work in Pragmatics. Jacob Mey's research interests concern all areas of pragmatics, with an emphasis on the social aspects of language use, the pragmatic impact of computer technologies, and the pragmatic use of literary devices. 
do velho ditado "Dizer não é fazer", mostro que as palavras realmente têm um efeito (o que os filósofos e linguistas têm tentado entender, utilizando os conceitos de 'ato de fala' ou 'ato pragmatico'), e que os constituintes legais desta 'força' são precisamente o que faz com que os atos contratuais sejam válidos. Aqui, também, as palavras às vezes podem ser omitidas, ou substituídas por ações, desde que o contexto o permita. Baseado em alguns casos históricos e contemporâneos, o artigo sugere, além disso, como as palavras de fato podem fazer a diferença em uma variedade de contextos: sociais, legais e outros. O ângulo pragmático (isto é, a orientação para o utilizador) é sempre primordial, e as nossas palavras devem obedecer às condições pragmáticas, muitas vezes chamadas de 'affordances', da situação em que elas estão sendo proferidas.

Palavras-chave: atos de fala (pragmáticos), normas legais, contratos, sequencialidade

\section{Introduction: 'Saying it don't make it so'-or does it?}

One often hears it said: "Saying it don't make it so" - and the meaning of the saying is that in situations where things have to be decided on, done, planned, executed, and so on, certain people are prone to engage in lengthy diatribes about what should be done, rather than doing something in order to realize the plans. In such a situation, the other participants in the planning may be tempted to shut up the talker by remarking that no matter how much s/he discourses on the subject, nothing will happen until s/he does something about it, for indeed, 'saying it don't make it so'. Similarly, when people are trying to make the computer behave by writing a program, the received wisdom has it that talking about it in terms of what could be done or should be done doesn't amount to the practice of writing some effective lines of code that work. Again, 'saying it don't make it so'.

The present article endeavors to place the saying in a wider context, where the force of words is put into perspective by referring to various contexts: sacral, secular collaborative, familial supportive, and not least legal in all senses of the term. It will be shown that indeed, 'saying' things may make a difference — in many cases the difference 
that makes a difference, sometimes of life and death; a difference that is of importance not only for those who hear, but also those who say the words, as is especially obvious when it comes to consider the legal implications of one's use of language. Here, I am not only thinking of words used in the courts, at the police station, during the hearings prior to confirmation of an official's appointment, but also of the language being employed in the private sphere of the testimony, the mediation, the contractual situation, and so on.

More generally, the notion that one's words have consequences not just for the here and now, but also in a wider, global context of legal interpretation and in future, not yet realized scenarios, has been a familiar one ever since the days of the Babylonian code of Hammurabi, the Greek Sophists, and the Judeo-Christian-Islamic tradition of the Bible, Talmud and Qur'an. As St. Matthew has it, "everything that man shall say, they shall give an account thereof in the day of judgment; for by thy words thou shalt be justified, and by thy words thou shalt be condemned" (MATTH. 12, vers. 36-37).

\section{Questioning the wisdom of the saying: Speech acts and the law}

On closer looks, however, the adage 'Saying it don't make it so' loses much of its credibility. In effect, there are many 'sayings' that do 'make it so': they 'do' something to the sayer and the listener(s): addressee(s), overhearers, and bystanders, and to the world around them. In the following, I will consider several cases in point, chiefly from the world of legal obligations, their transgressions and possible ensuing sanctions.

\subsection{Speech acts and their effects: General}

It is commonly recognized that speech acts, however one prefers to classify or subdivide them, all have this in common that 
they 'act': in the German linguist Philipp Wegener's words, we are looking at a linguistic activity (sprachliches Handeln) that consciously and effectively wants to make an impression on the 'actees' and their environment (Wegener 1921). In saying this, Wegener anticipated the development of speech act theory by several decades; in the end, it was a philosopher, John Austin, who coined the immortal phrase 'doing things with words' (1962) which became the take-off point for the trends in philosophy and linguistics that culminated in the late nineteen eighties, when 'pragmatics' was introduced as a member in good standing of the linguistic dynasty of 'syntax, semantics, and pragmatics' (a division adapted from earlier work by the philosopher Charles Morris, working in the Peircean tradition; 1938).

Take the simple speech act of 'promising'. By uttering the words 'I promise' (or performing an act of the same quality as that of the 'canonical' expression to promise), I create a bond, an obligation, on myself as utterer to perform the content of the promise. Moreover, the promissee, by accepting the promise, is bound to recognizes this bond and act accordingly.

\subsection{Speech acts and their effects: Legal}

But there is more. Wegener talked about the 'environment' that is subject to the effects of the acting. In the case of the promise, we have instances where society visibly and openly 'interferes' by ratifying the act, and making it into a legal obligation. Some of us may be old enough to remember the classical cases of 'broken promises', often exploited in lightweight early twentieth century novels: a chorus girl or some other female from the vida could successfully sue a lord or other dignitary from whom she, following a short time liaison, had extracted a promise to marry. Breaking his promise would have serious consequences for the promiser, so in most cases the matter was settled out of court, mediating a handsome compensation to the promissee. However, with changing societal mores and in an ever more democratic society, the 'interference' stopped, and most of the attempted cases never made it to, or were thrown out by, the courts. 


\subsection{Speech acts and their effects: Institutional. Some cases}

In the case of institutionalized promises, such as those encountered in marriage in many cultures and religions, a further legal dimension comes into play: that of the official representative of the society, or particular segment of society, that administrates social contracts such as marriage (with the ensuing obligations of moral and material nature, such as the proprietorship of goods, the assignment of right of succession, and so on). Sometimes, such acts take on rather derisory forms, such as when people sell rights and privileges to goods and positions that are not even theirs (or do not even exist officially, like 'rights' on lunar property).

\subsubsection{A case from history}

Here is an example from medieval history. On 18 March, 1277, a certain Princess Maria of Antioch, 'sold' her chartered rights as Queen of Jerusalem to a competing pretender, King Hugh of Cyprus, for four thousand pounds of gold and an annuity of four thousand pounds tournois. ${ }^{2}$ The pretenders' rights were based on intricate patterns of inheritance (respectively, being a niece once removed of the grandmother of the former Queen versus being an grandson of a half-sister to the Queen) and to energetic politicking on both sides; and even though the crusader-founded Jerusalem Kingdom by the time of the deal had been reduced to a few scores of coastal miles along the Mediterranean, and no recent sovereign or pretender ever had set foot in his or her property, the Princess's activity of resignation effected a change in the environment: now the successful pretender

2. The Tours pound, or livre tournois, was a medieval coin and accounting unit worth 6 écus. As unit of accounting, it was in use as late as during the 19th century (for instance, in 1803, the cost of the Louisiana purchase by the USA was specified both in dollars, francs, and pounds tournois. (Source: Wikipedia).

At the time of the Princess' resignation, a Tours pound was worth about one eighth of a gold florin, or of a pound sterling. The ' 4,000 pounds of gold' that were stipulated must have been in actual weight, at the time around 450-455 modern grams, as still is the case for today's weight unit, the US and British pound. 
was free to use the rights to the Kingdom as a bargaining chip in negotiations with other nobles and potentates of the period, such as the ambitious Charles of Anjou, who dreamt of establishing a grand fiefdom all across the southern Mediterranean (Source: RUNCIMAN 1958, p.188-189).

\subsubsection{Marriage and more}

Closer to home, the current marriage ceremonies in the Christian churches usually require the presence of an official representative, a priest or minister, who not just is witness to the act (there are separate charges for that), but the one who effectively 'performs' the marrying act by pronouncing words to that effect (such as Ego vos conjungo in matrimonio in nomine Patris et Filii et Spiritus Sancti 'I hereby join you in matrimony in the name of the Father, the Son and the Holy Ghost'; from the Roman Catholic marriage ritual). Here, the priest's 'saying' certainly, within the confines of the religious environment, 'makes it so', that is, it makes the marriage happen, as well as providing it with legal validity in those countries where the marriage in the church still is recognized as a contract in the context of secular law (e.g. the Scandinavian countries, or most of the Catholic countries of Central and Southern Europe).

\subsubsection{Speech acts and their effects: Religious}

To stay in the sphere of performance, doing miracles by uttering specific words, undoubtedly belongs here as well. Innumerous are the cases where saints and other godly persons have changed the environment by 'saying' something: Joshua commanding the sun to stand still at Gibeon, the moon in the valley of Ayalon (Joshua 10:12), Jesus telling the lame man to pick up his bed and walk (Mark 2:9), Jesus changing water into wine at the Cana wedding (John 2:1 11), or making the deaf and dumb man hear and speak (Mark 7:34), where in the latter case even the exact wording of the speech act has 
been recorded (in Aramaic: Effata, 'Open up'), and so on; and even if some may remain skeptical as to their real content, the Biblical stories show a correct understanding of the 'power of words', as manifested to the faithful present at the time, who appropriately exclaimed: "What kind of speech [read: speech acting] is this?" (LUKE 4:36).

\section{Words, the law, and beyond}

So far, the emphasis has been on the actual wording of the speech acts; we have not paid much attention to the physical and other acts accompanying the words. Yet, in many instances this aspect of our social/communicative activities needs to be brought out into the open, since it often in parasitical ways substitutes for, and subsumes the act. The interest that these 'pseudo-acts' generate is not just academic: there is a whole territory of legal 'no-man's land' where acts such as opening an envelope, breaking the seal on a package of software, pretend to be legally valid acts that commit the actor to certain responsibilities.

\subsection{The internet}

How to judge, for instance, the wording that one routinely encounters when ordering some goods via the internet: 'By pressing the button "Buy now" you agree to all the conditions and restrictions specified in the sales offer'? Sometimes a special 'understand' button has to be pressed prior to the sale; here one is admonished to act only after having read the sales conditions and understood them. In all these cases, a contract is entered into without the usual safeguards, hedges and negotiation possibilities; while some countries, such as Norway and Denmark, have a general 'opt-out' period of two months for this kind of 'contracts', in specific cases the seller may bind the buyer/button presser by stating that the goods offered only can be 
taken back within a very short span of time (e.g. at most 24 hours in the case of internet ticket sales by the Danish State Railways). The buyer's options in these transactions are usually extremely limited, and even if reading the 'fine print' may help one's understanding, the whole process is a one-way street: 'If you don't like my conditions, then there is no deal' (a variant of 'if you don't like the smoke, stay out of the kitchen').

As I said earlier, the whole territory of internet interactions is still largely uncharted as to its legal implications, but the tendency seems clear: it's a seller's market, the service providers have all the power, and for the consumer it's a lose/lose proposition. The pragmatic acts of buying and selling bypass and void any of the conditions formulated for 'regular' speech acts, and the user perspective is virtually absent.

\subsection{Reading and other contracts}

Elsewhere, I have raised the question whether reading can be considered a 'pragmatic act' (Mey 2000; cf. also Iser's 'act of reading', 1980). There, I argued that opening a novel or a collection of poems is tantamount to entering into a contract with the author, who introduces one into his or her particular 'poetic space'. In the same way, one could maintain, the act of breaking the seal on a package amounts to entering into a contract with the seller. The difference, however, is that in the latter case, the element of 'free will' is totally absent: the transaction takes place entirely one the one party's premises, and the only option valid is the one of 'take it or leave it'. Moreover, the user's reading of the contract (which most people who order stuff on the internet presumably do not do) is for a one-time interaction only, as it has to do with the transaction in question to the exclusion of everything else; no relationship is being built, nor is a commonality of interest developed beyond the punctual fact of 'agreeing to buy on seller's terms'. 


\subsubsection{A historical case of 'reading and understanding': the requerimiento}

As to reading itself, it too has a volitional aspect: the Augustinian phrase tolle lege ('pick it up and read', spoken to the saint and referring to the bible in front of him, which he is said to have opened at random at Romans $13: 13,{ }^{3}$ thereby triggering his conversion) would have been void and without effect if the hearer had not had the will to read, and to perform in accordance with the words perused. However, forcing people to read a document does not enable to understand and grasp its implications, and thus make them legally bound by its content. Specifically, in the case of an illiterate audience, when the reading is done by someone else, the creation of a binding obligation arising from the text-as-read remains highly problematic.

As a case in point, consider the requerimiento, a document drawn up by the Dominicans at the Spanish court in 1514, and meant to assist the conquistadores of the newly discovered American lands in their work of 'pacification' and Christianization. In essence, the document states that God has made the Pope his representative on earth, and that His Holiness had given the Spanish King the right and duty to conquer their newly-acquired territory and subjugate its inhabitants in order to make them obedient to the Holy See and the Spanish Crown, for as good Christians, to be rewarded with the hopes of eternal salvation. The people whose lands the Spanish had invaded were given the choice of subduing themselves to the Spanish Crown, or being deprived of all their human rights, and basically reduced to slaves or chattel. Although the requerimiento explicitly states that "we will not force you to become Christians", the subtext (and even some of the clear text) stipulates all kinds of punishments for those who do not let themselves be "received" under the "yoke and obedience to the Church and His Majesty" (ZAVALA 2001, quoted BLOCKMANS 200, p. 106-107).

3. "Not in rioting and drunkenness, not in chambering and wantonness, not in strife and envying, but put on the Lord Jesus Christ, and make no provision for the flesh to fulfill the lusts thereof" - hence quite the opposite of St Augustine's lifestyle until then... 
As the naked facts of history teach us, however, the true in- and content of the requerimiento as well as its (ab)use by the colonizers became abundantly clear on November 16 of 1532, when Francisco Pizarro, having had the document read by the Spanish friar Vicente de Valverde before the 5,000 inhabitants of Cajamarca, Peru, in the presence of the Inca Atahualpa, had them all massacred and the Inca taken prisoner, because neither the natives nor their sovereign did manifest any wish to be 'received' or 'saved'. (Source: OESTERREICHER, 1999).

\subsubsection{The pragmatics of contracts}

What the case of the requerimiento shows us, in the legal context of a contract that has not been sufficiently explained and discussed, is mainly this:

Pragmatically, a contract is a relationship between users. If for some reason, one user is not equipped to deal with the terms of the contract, or even understand them properly, the contract can never be legally valid (take the case of people who are declared non compotes mentis, or who are under age). But how about people who willingly 'press the button', having been informed that this equals an act of acceptance? I would argue that as long as there is no way to escape the contract conditions (no matter what the button 'says'), there is no legal binding contract, and the validity of the agreement is doubtful.

The cases of 'breaking the seal', 'pressing the button' and so on that were mentioned earlier, are all actions taking place in what could be called a 'situation of no return', comparable to one where a promise is given under duress. The force of the written words by themselves can never aspire to equal the obligation that arises from a contract that is entered upon freely and without encumbrances or 'killer clauses' of the type 'Whoever reads this is crazy'-like the graffiti that we used to scrawl on walls and fences when we were young. 


\section{Contextual (consensual) acts}

The patres conscripti, members of the Roman Senate, had their own way of voting on proposed laws and ordinances: they would 'vote with their feet'. By moving to the one or the other side of the Senate Hall in the Capitol they would signify their agreement with, respectively objection to, the proposed measures. This 'voting movement' was called pedibus ire in sententiam, literally 'using one's feet to manifest one's vote'. The idea that moving one's body may be taken as a sign of assent or dissent is of course not restricted to the ancient Romans; we all use our heads every day to manifest our adhering to, or dissenting from, what has been said. True, the actual realization of the move may differ, such that a modern Greek person's downward head move has to be taken to mean his/her assent (as opposed to an upward move for dissent), while the left-to-right, right-to-left head shake, common in Western European culture as a means of manifesting dissent, is absent in Greek; all of which is apt to cause a good deal of misunderstanding for Westerners, when confronted with the Greek practice. Note, too, that the Greek head moving custom predates contemporary touristic difficulties by several millennia: compare that the Romans used the linguistic distinction involved in the moves of $a d$-/an- vs. $a b-n u o$ ('moving one's head to', respectively 'away from' the addressee) in exactly the same way, and they manifested it physically by moving their heads in what we now see as a typically 'Greek' fashion. ${ }^{4}$

From the same sphere of classic civilization, we retain even today the expressions 'thumbs up' vs. 'thumbs down' (to manifest approval or disapproval), in analogy to what the Romans used to do when confronted with the question whether or not to spare the life of a defeated gladiator in the favorite reality sports of the day, euphemistically called the ludi circenses, 'circus games' (the circus, at Rome represented by the Coliseum, functioned in many ways as the Plazas de Toros or the football fields in certain contemporary societies).

4. Compare the inscription on the Grand Seal of the USA: "[Deus] Annuit Coeptis", '[God] has approved of what was started'. 


\section{Legal (Speech?) Acts}

What all these cases show is that 'saying' not always or necessarily implies using one's voice (or writing). Legally, a pragmatic act such as moving one's hands at an auction or in the context of a gladiatorial session may have the effect of a speech act, well and properly executed, on one condition: that the context is such that the act is executed and recognized in accordance with the societal conventions. Thus, the 'show of hands', often practiced at meetings in the Anglophone world to see if there is a majority to second a proposed motion, may be recognized as legal only if no one protests (actually, the practice can always be questioned by anybody who feels uncertain about the correct count). Consequently, the 'show of hands' and other, similar practices are never the last 'words' in these particular contexts.

Which brings us back to the validity of the earlier mentioned acts such as 'pressing a button' or 'breaking a seal'. Here, too, the context decides on the legality and/or validity of the action; moreover, in a given contextual setting, even barely perceptible, minute motions of the head or fingers (or even the eyebrows) may give rise, within the particular context, to a settlement of contracts. (Compare that teachers of courses such as Citizenship 301, when chaperoning their freshman students to manifestations of social life like public fish or antique auctions, have to admonish the inexperienced audience to keep perfectly still during the entire session, and not move a single limb or utter a single word, because indeed 'whatever is said may be counted in your (dis)favor').

\section{Normative conventions, contexts, and legality}

Elsewhere (Mey 2000), I have considered the normative aspects of contextuality: how, by entering a well-defined 'space' (such as the literary universe created by an author), one voluntarily submits oneself to the norms and rules that are current in that space. One's acceptance 
of the societal norms is particularly relevant in our case, where acts of the kind that I referred to above, only can be properly understood, evaluated, and honored when they are put in relation to their contexts. The 'normative' aspect of that context is intimately related to the society in which the norms have been formed; sometimes, however, or even much of the time, those norms are kept 'under cover', so to speak, to be trotted out only in case of necessity, not seldom to the surprise of the people who are being 'normed'.

\subsection{An Israeli case}

The Israeli scholar Sol Azuelos-Atias, in her work on the norms and conventions surrounding Israeli jurisprudence, has painted a rather disturbing picture of the way justice is administered vis-à-vis certain of the original inhabitants of Palestine. There are a great many 'contextual', but rather vague, notions around in the legal discourse of the State of Israel; among the most controversial ones are those like 'the ordinary Israeli' (ha-yisraeli ha-memuca), or 'the reasonable Israeli person' (ha-adam ha-savir ha-yisraeli), a mythical beast supposed to represent the norm for conduct and behavior of all Israeli citizens (Azuelos-Atias 2007: 51). The notion does not take into account the fact that there are many Israeli citizens who do not follow the 'norm': for one thing, they don't speak or understand Hebrew (their mother tongue is Arabic), and thus are not able to follow juridical discourse in the former language. ${ }^{5}$ In the courts, the notion is used to discriminate againjst people who do not understand the language of the procedures (Hebrew); and even if one translates concepts such as 'ordinary' or 'reasonable' into Arabic, it is still the Israeli norm or 'being ordinary' or 'reasonable' that is decisive. This holds even for such mundane cases as how to handle notions of time and space, which may be quite different in the two languages and cultures, Hebrew and Arabic; e.g. does the preposition 'over' in a

5. I am not even talking here about the one million Russian immigrants, whose Hebrew is quite shaky, to say the least. 
spatial context include the terminus ad quem? Is "over him" the same as, or different from, "facing him" in Arabic vs. Hebrew-a crucial distinction in an actual court case discussed by the author; AzuelosAtias 2007: 130?)

\subsection{Future legal acts and sequentiality: A pragmatic angle}

In pragmatic thinking, the user is paramount. That means that all acts of speaking have to be related to the user - not just the speaker, but including the hearer(s), possible bystanders and overhearers (ratified or not), and in the end even hearers who are not yet 'there' in time and space: the future generations. To take an obvious example (due to my colleague Uwe Kjær Nissen in personal communication), a person writing his of her last will and testament envisions the recipient of the message as being potentially far away in the future (of course depending on the point of time of writing the will). The pragmatic act of making a will takes necessarily the time dimension into consideration, both as regards the 'speaker' ("My last will and testament") and the 'destinees' (to be identified in the succession of time, at the moment of opening the testament). Clearly, the act of making a testament would lack sense if one did not take these temporal, spatial, and personal dimensions into account.

As I have argued elsewhere (Mey 2013), what has been called 'sequentiality' in Conversation Analysis has a great impact also for speech act theorizing. For instance, what can be proposed and discussed in speech act theory as a simple case of 'promising', becomes immensely complicated once one counts in the dimensions mentioned above; and while it is true that no speech act comes into its own, unless acknowledged by the receiver (an insight already familiar to classical speech act theory), one must go further and say that speech acts, to be evaluated properly as pragmatic acts (see Mey 2001: ch. 8), have to be situated in light of what follows, not just of what precedes. 


\subsection{Sequential apology}

Thus, an act of apologizing, taken by itself, is just that; but placed in the context of a (semi-)official situation such as the court room, or visiting a public place like a museum, the apology issued by an official representative of the institution in question may amount to a warning, or even a (negative) injunction, as the following example (adapted from Haugh 2007: 86) shows:

[A visitor to the Edo-Tokyo Museum is sitting down on a bench, starting to unwrap a package of food. A museum attendant, upon seeing this, approaches the visitor and says):

(Attendant) Mooshiwake gozaimasen ... mooshiwake gozaimasen

('I'm very sorry ... I'm very sorry ...')

(Visitor) A, ikenai?

('Oh, it's not allowed?')

(Attendant) Mooshiwake gozaimasen ...

Notice here that the Japanese expression Mooshiwake gozaimasen ('I'm very sorry') has nothing to do with the actual situation as such; it is a very general, very polite way of saying 'Sorry'. No mention is made of regulations, prohibitions, propriety, food \& drink; no appeal is made to authority, visitor behavior, sanctions, and the like. Yet, this apology, in function of its character as an 'indirect speech act' of admonishing/reminding/prohibiting and so on, is immediately taken up by the visitor, who interprets the situated utterance of 'apologizing' as a pragmatic act of 'not allowing'.

Accepting the sequentiality of our acting (Mey 2013) is thus a natural consequence of admitting the societal, legal dimension into our thinking about speech acts. Humans evolve over time, and so does their use of language - not just seen as a static, 'instant' picture of what is actually being said (as Saussure seemed to believe), but as a perspective on what the things said mean, and may come to mean, in the 
wider context of space and time. This 'opening up' of the hermetically closed speech act context is in my opinion one of the most valuable aspects of pragmatic thinking: it guarantees that we are not 'beating the thin air' of linguistic abstraction by constructing decontextualized phrases, but are taking up the challenge of speaking to, acting on, the world, and by doing so, change it.

\section{Conclusion: A legal difference}

In effect, only in the sense defined here (and emphatically so), 'saying something' makes a difference. Wittgenstein used to claim that uttering a true sentence changes the world. Hence, 'saying it don't make it so' is only true under certain, narrowly defined conditions, valid for specific situations (such as developing a computer program internally). In a wider contextual (specifically, legal) environment, 'saying it' does make something happen — and the effect of one's speech is mostly irreversible, as it has changed the world in some respects. In other words, what we need is to recognize and highlight the inevitable volitional orientation of our speech acting that seems to have lacked in discussions on how to 'do things with words'. (Re-) introducing this orientation (among other things, in the guise of the 'pragmatic act', as I have suggested elsewhere; Mey 2001) may result in a more fruitful treatment of speech acting, by alerting users to the implications of their acts in space and time.

'Nobody is an island', it has been said, meaning that nobody can pretend to live in 'splendid isolation', each in his or her little closed environment. The corollary is that our words, once spoken, will cross mountains, rivers, oceans and other boundaries to revert to their original utterers in forms they perhaps did not anticipate, but are bound to live with, and accept, as authentic, binding interpretations.

Recebido em: agosto de 2013

Convidado para este volume jam@sdu.dk 


\section{References}

AUSTIN, John L. How to do things with words. Oxford: The Clarendon Press. 1962.

AZUELOS-ATIAS, Sol. A pragmatic analysis of legal proof of criminal intent. Amsterdam: John Benjamins. (Reviewed by Jacob L. Mey in RASK: International Journal of Language and Communication, 34: 118-123), 2007.

Blockmans, Wim. Emperor Charles V 1500-1558. London: Arnold. 2002.

HAUGH, Michael. The constitution of politeness implicature in conversation. Journal of Pragmatics 39: 84-110. 2007.

ISER, Wolfgang. The Act of Reading: A Theory of Aesthetic Response. Baltimore \& London: The Johns Hopkins University Press. [Orig. German title: Der Akt des Lesens: Theorie ästhetischer Wirkung.] 1980 [1976].

MEY, Jacob L. When voices clash: A study in literary pragmatics. Berlin: Mouton de Gruyter. 2000.

MEY, Jacob L. Pragmatics: An introduction. Oxford: Blackwell [Second edition]. 2001 [1993].

MEY, Jacob L. Turning the tide of speech. Keynote address at the Third International Symposium 'Meaning, Context and Cognition' (MCC 2013), University of Lódz, Poland, 11-13 April 2013.

MORRIS, Charles H. Foundations of the theory of signs. Chicago: University of Chicago Press. (= Rudolf Carnap et al. (eds.), International Encyclopedia of Unified Science, Vol. 2:1). 1938.

OESTERREICHER, Wulf. Dialogue and Violence: The Inca Atahualpa meets Fray Vicente de Valverde, Cajamarca, Peru, 16th November 1532. In: Andreas H. Jucker, Gerd Fritz and Franz Lebsanft (eds.), Historical Dialogue Analysis, 431464. Amsterdam: John Benjamins.1999.

RUNCIMAN, [Sir] Steven. The Sicilian Vespers: A History of the Mediterranean World in the Late 13th Century. Cambridge: Cambridge University Press. (Penguin Pelican edition, 1969, subtitled 'The rising which brought about the overthrow of the universal papal monarchy'). 1969 [1958].

WEGENER, Philipp. Der Wortsatz. Indogermanische Forschungen 39: 1-26. 1921.

ZAVALA, Silvio A. Las instituciones jurídicas en la conquista de América. México: Porrúa. 2001 [1983]. 